\title{
Article
}

\section{Butyl Rubber-Based Composite: Thermal Degradation and Prediction of Service Lifetime}

\author{
Phuong Nguyen-Tri ${ }^{1, * \mathbb{D}}$, Ennouri Triki ${ }^{2}$ and Tuan Anh Nguyen ${ }^{3}$ \\ 1 Department of Chemistry, University of Montreal, Montreal, QC H3T 1J4, Canada \\ 2 Department of Mechanical Engineering, McGill University, Montreal, QC H3T 1E2, Canada; \\ ennouri.triki@mail.mcgill.ca \\ 3 Institute for Tropical Technology, Vietnam Academy of Science and Technology (VAST), Hanoi 122100, \\ Vietnam; ntanh2007@gmail.com \\ * Correspondence: phuong.nguyen.tri@umontreal.ca; Tel.: +1-514-340-5121 (ext. 7326)
}

Received: 11 April 2019; Accepted: 26 April 2019; Published: 5 May 2019

\begin{abstract}
Butyl rubber-based composite (BRC) is one of the most popular materials for the fabrication of protective gloves against chemical and mechanical risks. However, in many workplaces, such as metal manufacturing or automotive mechanical services, its mechanical hazards usually appear together with metalworking fluids (MWFs). The presence of these contaminants, particularly at high temperatures, could modify its properties due to the scission, the plasticization and the crosslinking of the polymer network and thus lead to severe modification of the mechanical and physicochemical properties of material. This work aims to determine the effect of temperature and a metalworking fluid on the mechanical behavior of butyl rubber composite, dealing with crosslinking density, cohesion forces and the elastic constant of BRC, based on Mooney-Rivlin's theory. The effect of temperature with and without MWFs on the thermo-dynamical properties and morphology of butyl membranes was also investigated. The prediction of service lifetime was then evaluated from the extrapolation of the Arrhenius plot at different temperatures.
\end{abstract}

Keywords: polymer aging; swelling behavior; protective glove materials; elastomers; composites; rubber

\section{Introduction}

Rubber is one of the most important materials for various industries, especially in petroleum, construction [1] and protection material sectors [2,3]. Protective gloves are often covered by an elastomeric coating to protect against chemical and mechanical damages due to its good resistance against abrasion, oils and chemicals, and its excellent damping properties [4-12]. However, the swelling phenomena involving the degradation of the mechanical properties of these materials have often been observed [13]. Butyl rubber-based composite (BRC) is one of the most effective materials against chemical risks $[4,13]$. However, this material is sensitive to nonpolar solvents or metalworking fluid. These non-polar compounds can easily penetrate into the polymer and lead to a dramatic change of material properties. These problems represent a large risk for users and thus require a better understanding of the problem $[13,14]$. Like other polymers, butyl rubber-based composites can be affected by oxidation, and this effect becomes more intensive at a high temperature.

The swelling characteristics of rubbers are related to the deterioration of mechanical properties and may affect their failure mechanics. Currently, there are no models to predict the failure mechanisms in the presence of industrial contaminants. Several investigations have been reported on the effect of industrial contaminants on the morphology, mechanical properties and structure of glove material. In previous works [15-24], we reported that polymers and composites [16-20,22,23,25-41] can be 
degraded by several aging agents such as heat, water, humidity, oxygen, ozone and various other environments factors [16-24]. The scission, crosslinking and plasticization of polymer networks may occur and led to severe deterioration of the mechanical and physicochemical properties of the material [42], which are quite important with regard their applications in various fields of mechanical engineering.

Many researchers have attempted to understand the relationship between morphological and property changes within the microstructure of rubber material [43], especially with a failure mechanism of elastomer, by using several traditional test methods, including the tensile test, strain-stress relation and compression measurements [44-46]. Mooney-Rivlin's equation is usually used to evaluate the property-structure relationship of material by analyzing the tensile stress-strain curves of materials. In this model, Rivlin $[47,48]$ proposed an extension of the Mooney's model by describing $W$ as a polynomial series in $\left(I_{1}-3\right)$ and $\left(I_{2}-3\right)$ :

$$
\mathrm{W}=\sum_{\mathrm{i}, \mathrm{j}=0 \text { C Cij.(I1-3) }} \text { (I2-3) }^{\mathrm{j}} \text { with } \mathrm{C}_{\infty}=0
$$

During a simple tensile test, we define:

$$
\mathrm{I}_{1}=\lambda^{2}+2 / \lambda ; \mathrm{I}_{2}=1 / \lambda_{2} ; \mathrm{I}_{3}=1
$$

The stress $\sigma_{n}$ is given by the equation:

$$
\sigma_{\mathrm{n}}=2\left(\lambda-1 / \lambda_{2}\right)\left(\mathrm{dW} / \mathrm{dI}_{1}+\mathrm{dW} / \lambda \cdot \mathrm{dI}_{2}\right)
$$

According to the behavior law, we can still write:

$$
\sigma_{\mathrm{n}}=\lambda \cdot \mathrm{dW} / \mathrm{d} \lambda+\mathrm{dW} / \lambda \cdot \mathrm{d} \lambda_{2}
$$

From which:

$$
\sigma_{\mathrm{n}}=2\left(\mathrm{C}_{1}+\mathrm{C}_{2} / \lambda\right)\left(\lambda-1 / \lambda^{2}\right)
$$

where $W$ is the density of deformation energy, $\lambda$ is the elongation of material and $C_{1}$ and $C_{2}$ are two elastic constants associated with network structure and the flexibility of the network, respectively. According to Equation (5), the plot of $\sigma_{\mathrm{n}} / 2\left(\lambda-1 / \lambda^{2}\right)$ as a function of $\lambda^{-1}$ should be linear and the $C_{1}$ constant is directly calculated by extrapolating the linear portion of the curve up to $\lambda^{-1}=0$, and the $C_{2}$ constant is the curve slope. In the molecular aspect, this constant $C_{1}$ of Mooney-Rivlin's model is characterized by the density of crosslinking between elastomer chains [49,50]. It can be used to evaluate the physical manifestation of the degree of crosslinking $\mathrm{N}[51,52]$.

$$
\mathrm{N}=2 \mathrm{C}_{1} / \mathrm{kT}
$$

The constant $C_{2}$ is associated with the cohesion forces (intramolecular bonds and interchain) and reinforcement-matrix interactions [52]. This constant also reflects the flexibility of the structure of the material [53]. It depends on the degree of vulcanization, which increases with the increasing of the crosslink density [53]. The values of the two constants $C_{1}$ and $C_{2}$ that can be determined during the tensile tests allow for studying the influence of the crosslinking degree and network structure on the stiffness of the material. Gordon [52] determined the Young's modulus according to $C_{1}$ and $C_{2}$ :

$$
\mathrm{E}=6\left(\mathrm{C}_{1}+\mathrm{C}_{2}\right)
$$

It reported that the constant $C_{1}$ usually remains constant with the variation of the swelling degree of the polymer material, while the constant $C_{2}$ decreases with the increase of the swelling degree [54-56]. It lacks a systematic ability to research the effect of temperature and metalworking on the morphology, properties and structure of elastomer materials. 
In this study, a butyl rubber membrane, representing a common material used in protective gloves, was used to determinate the swelling characteristics to metalworking fluid at various temperatures ranging from $80^{\circ} \mathrm{C}$ to $120^{\circ} \mathrm{C}$. The elastic behaviors dealing with elastic constants, crosslinking density and modulus were continuously followed during the contamination procedure to evaluate the dominant parameter on polymer deterioration. The modification of morphology, tensile properties and physicochemical properties were also investigated.

\section{Materials and Methods}

\subsection{Materials}

The butyl rubber-based composite (BRC) membranes used in this work were made from butyl rubber with carbon black fillers. These commercial products (thickness of $\sim 1.6 \mathrm{~mm}$ ) were kindly supplied by MCMaster-Carr Inc. (Montreal, QC, Canada). An industrial metalworking fluid (MWF) used in this work, namely Milform 64 SST, was directly purchased from a company in the metalworking sector in Quebec, Canada. The chemical composition can be found in our previous publications [57,58]. The carbon black filler content in composite membranes was estimated to be about $52 \mathrm{wt} \%$ (by thermal gravimetric analysis (TGA) measurement).

\subsection{Contamination Procedure}

The elastomer membranes having the mass $\left(m_{0}\right)$ were immersed into MWF for different periods of time for the measuring of the swelling index changes according to the American Society for Testing and Materials (ASTM) D471-12 standard. They were then delicately wiped by thick wiping papers to remove the excess oil on the sample surface and reweighed $\left(m_{t}\right)$. The process was repeated until a saturated state was reached. The swelling index $(M)$ was calculated according to the following equation:

$$
M(\%)=\frac{m_{t}-m_{0}}{m_{0}} \times 100
$$

where $m_{0}$ and $m_{t}$ are the weight of the samples before and after their immersion in contaminant, respectively.

\subsection{Scanning Electron Microscopy (SEM)}

The scanning electron microscopy model Hitachi S570 was used to investigate the morphology and the fractography changes of samples before and after the contamination process. These observations served to examine the failure modes of morphology changes of the elastomer materials.

\subsection{Tensile Tests}

Tensile properties of elastomer membranes were measured with the dog bone rectangular samples. Measurements were performed with an Alliance 2000 (MTS) universal testing machine equipped with a $1000 \mathrm{~N}$ load cell and operated at a cross-head speed of $500 \mathrm{~mm} / \mathrm{min}$ according to the ASTM D412-06 standard test method. For each condition, three replicates were measured, and the results were averaged. Figure S1 shows an example of train-stress curves of an original BRC. The samples were then placed into an oven to control the aging temperature. The samples were removed for each period to perform the analysis.

\subsection{Thermal Gravimetric Analysis (TGA)}

TGA was carried out with original and aged composite samples to evaluate the percentage of filler content and the effect of the aging process on the sample weight loss as a function of time. TGA was carried out in a nitrogen atmosphere at a heating rate of $20^{\circ} \mathrm{C} / \mathrm{min}$ using a Parkin Elmer TGA model 4000. Thermograms were recorded from 0 to $800{ }^{\circ} \mathrm{C}$. 


\subsection{Dynamic Mechanical Thermal Analysis (DMTA)}

The dynamic mechanical thermal property of the non-aged and aged BRC samples was measured by Instruments (DMTA, Q 800) at a testing temperature ranging from $-100{ }^{\circ} \mathrm{C}$ to $0{ }^{\circ} \mathrm{C}$ with a heating rate of $5^{\circ} \mathrm{C} / \mathrm{min}$.

\section{Results and Discussion}

\subsection{Effect of Temperature on Mechanical Properties}

The influence of temperature on the viscoelastic properties of BRC was investigated at three different temperatures ranging from 80 to $120{ }^{\circ} \mathrm{C}$. Figure $1 \mathrm{a}$ shows the relationship between the constant $C_{1}$ and the exposure time. It demonstrates that the highest value of constant $C_{1}$ was observed at a temperature around $120^{\circ} \mathrm{C}$. At the beginning of the exposure $(\mathrm{t}<4 \mathrm{~h}), C_{1}$ underwent a significant increase, and then rapidly decreased before achieving a constant value. At a lower exposure temperature $\left(80^{\circ} \mathrm{C}\right.$ and $\left.100{ }^{\circ} \mathrm{C}\right)$, the variation of the constant $C_{1}$ was not significant, represented by a slight decrease of $C_{1}$ at the first hours of exposure then appeared to be converged to the similar value observed at $120{ }^{\circ} \mathrm{C}$. These results allow the confirmation that the stiffness of butyl is optionally increased with temperature, as reported in the case of a neoprene membrane which was exposed to a high temperature [59]. Figure $1 b$ shows the variation of $C_{2}$ as a function of exposure time at different temperatures. The variation of the constant $C_{2}$ at $80{ }^{\circ} \mathrm{C}$ appeared to be similar to that at $100{ }^{\circ} \mathrm{C}$, with a parabolic shape curve. An increase in $C_{2}$ at the first hours of exposition $(\mathrm{t}<4 \mathrm{~h})$ was observed, and then it slightly decreased with time. It can be attributed to the increase of cohesive force at the first hours of exposition time, followed by a decrease [54]. This physical phenomenon was completely different to that observed at a higher exposure temperature $\left(120^{\circ} \mathrm{C}\right)$. The constant $C_{2}$ decreased significantly from the first steps of exposure and went down to zero. These results are not surprising, and are in good agreement with the study published by Marck [54].
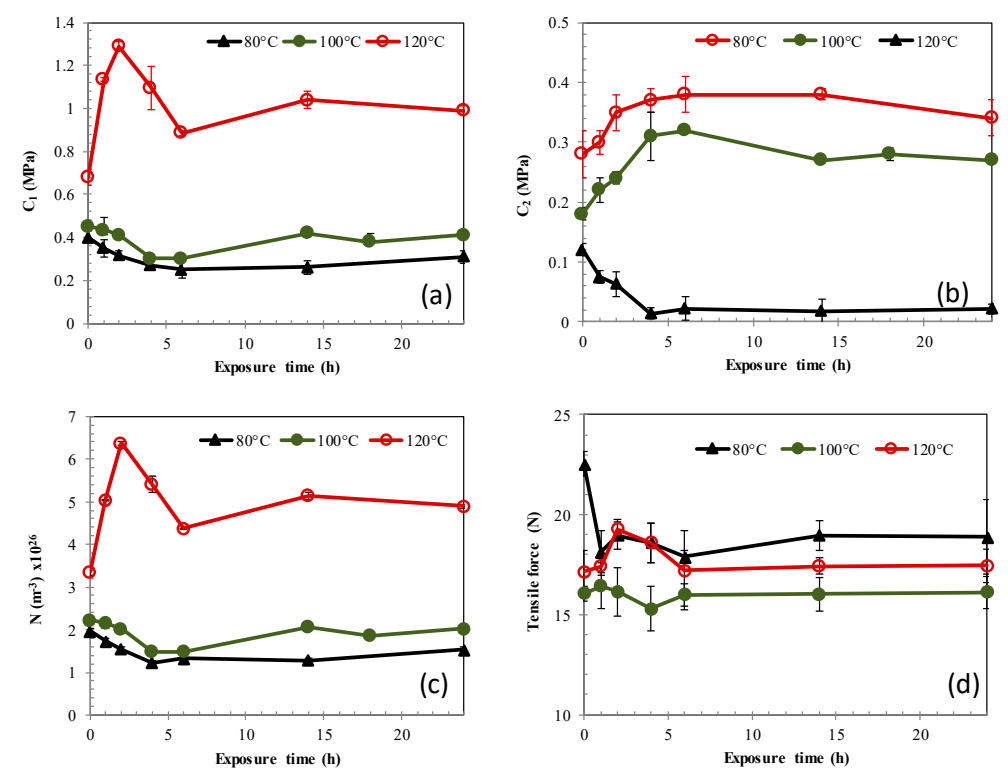

Figure 1. Effect of temperature on the mechanical properties of butyl rubber-based composite (BRC) as a function of metalworking fluid (MWF) exposure time (a) constant $C_{1} ;(\mathbf{b})$ constant $C_{2} ;(\mathbf{c})$ crosslinking density $(\mathrm{N})$; (d) tensile force.

The synergy between the variation of $C_{1}$ and $C_{2}$ was also investigated, and the results are shown in Table 1. This synergy is determined by calculating the theoretical Young's modulus by using Equation (7) and the experimental Young's modulus from the first linear region of the force-displacement curves (Figure 1d). The obtained results show that the rigidity of the butyl remains almost unchanged at $80^{\circ} \mathrm{C}$. 
However, a significant increase of Young's modulus with exposure time was recorded at $120{ }^{\circ} \mathrm{C}$. This can be attributed generally to the increasing of crosslinking density $(\mathrm{N})$ that may have occurred at a high temperature due to the vulcanization or reticulation of polymer chains. After $24 \mathrm{~h}$ exposure in MWF, the Young's modulus seemed to increase at 100 and $120^{\circ} \mathrm{C}$ (Figure 1c). Figure $1 \mathrm{~d}$ demonstrates the tensile force of BRC as a function of exposure time, and it can be seen that the rupture properties remained constant during all exposure times regardless of the exposure temperature. The variation of tensile strength at the break with exposure time was not significant. This implies that the BRC has a relatively high resistance to temperature for a short time and the latter does not affect the mechanical failure behavior.

Table 1. Young's modulus values of a butyl membrane exposed to various temperatures.

\begin{tabular}{|c|c|c|c|c|c|c|}
\hline \multirow{3}{*}{$\begin{array}{l}\text { Exposure } \\
\text { Time (h) }\end{array}$} & \multicolumn{6}{|c|}{ Exposure Temperature } \\
\hline & \multicolumn{2}{|c|}{$80^{\circ} \mathrm{C}$} & \multicolumn{2}{|c|}{$100{ }^{\circ} \mathrm{C}$} & \multicolumn{2}{|c|}{$120^{\circ} \mathrm{C}$} \\
\hline & $E_{\text {theo }}$ & $E_{\exp }$ & $E_{\text {theo }}$ & $E_{\text {exp }}$ & $E_{\text {theo }}$ & $E_{\exp }$ \\
\hline 0 & $4.08(0.42)$ & $3.40(0.04)$ & $3.78(0.06)$ & $3.00(0.05)$ & $4.80(0.30)$ & $4.11(0.16)$ \\
\hline 1 & $3.90(0.36)$ & $2.89(0.2)$ & $3.93(0.48)$ & $3.15(0.25)$ & $6.57(0.12)$ & $6.10(1.10)$ \\
\hline 2 & $3.99(0.30)$ & $3.01(0.09)$ & $3.90(0.10)$ & $3.20(0.13)$ & $8.120 .24)$ & $7.43(0.18)$ \\
\hline 4 & $3.78(0.24)$ & $2.99(0.03)$ & $3.66(0.36)$ & $2.88(0.18)$ & $6.65(0.66)$ & $5.45(0.85)$ \\
\hline 6 & $3.78(0.42)$ & $2.98(0.10)$ & $3.72(0.04)$ & $3.01(0.02)$ & $5.44(0.18)$ & $4.57(0.02)$ \\
\hline 14 & $3.84(0.24)$ & $2.98(0.09)$ & $4.14(0.09)$ & $3.27(0.01)$ & $6.35(0.36)$ & $5.08(0.14)$ \\
\hline 24 & $3.90(0.36)$ & $2.96(0.02)$ & $4.08(0.09)$ & $3.30(0.09)$ & $6.08(0.16)$ & $4.80(0.12)$ \\
\hline
\end{tabular}

Note: between parentheses: standard deviation (SD). $\mathrm{E}_{\text {theo }}$ : theoretical modulus. $\mathrm{E}_{\text {exp }}$ : experimental modulus.

\subsection{Effect of Simultaneous Temperature and Metalworking Fluid on Properties, Structure and Morphology}

In the working condition, glove materials are often in contact with hot MWFs, generated by friction of machine devices. This factor could directly affect the protective performance of the glove materials. The effect of simultaneous temperature and MWFs on the properties of butyl membranes was investigated. Figure $2 \mathrm{a}$ shows the variation of the constant $C_{1}$ as a function of expose temperature in the presence of a metalworking fluid (Milform 64 SST). As shown in Figure 2a, the changes of the constant $C_{1}$ with an exposure time at $80^{\circ} \mathrm{C}$ were substantially similar to that at $100{ }^{\circ} \mathrm{C}$, thus these two curves are approximately superposed. However, at $120^{\circ} \mathrm{C}$, the curve tendency is different when compared with that at lower exposure temperatures, where $C_{1}$ values dramatically dropped in the first hours of exposure and then tended to archive at a plateau region. Figure $2 \mathrm{~b}$ shows the effect of temperature and MWFs on the constant $C_{2}$. It demonstrates that the constant $C_{2}$ rapidly decreased with the exposure time and approached to zero after $24 \mathrm{~h}$ of exposition. Therefore, the cohesive strength of the inter-chain eventually became weak [54] and the viscoelastic behavior may have also been affected. The results are in good agreement with that observed by Gumbrell et al. [60] and Allen et al. [61] in studying the aging process of natural rubber to different solvents.

The calculation of the Young's modulus, in particular at $80^{\circ} \mathrm{C}$ and $100{ }^{\circ} \mathrm{C}$, highlights the effect of simultaneous temperature and contaminants on the rigidity of the material. A significant decrease of the Young's modulus as a function of exposure time was observed (Table 2). This could be attributed to the reduction of the cohesive strength of inter-chains. The rigidity of butyl at $120^{\circ} \mathrm{C}$ was unstable. The Young's modulus first increased, then decreased before achieving a plateau region. This variation was possibly related to the changes in the cross-linking density $(\mathrm{N})$ as shown in Figure 2c. This variation was due to the correlation between the constants $C_{1}$ and $C_{2}$. Similar behavior was also discussed by Nohilé et al. [4], demonstrating that the swelling of BRC by solvents led to an increase of the material rigidity due to the loss of fillers. The latter leads to a reduction of the tensile strength of BRC as shown in Figure 2d. It can be seen from these figures that the mechanical properties of the material were decreased regardless of what exposure temperatures were applied. It was observed that the longer the exposure time, the higher the loss of the mechanical properties. 

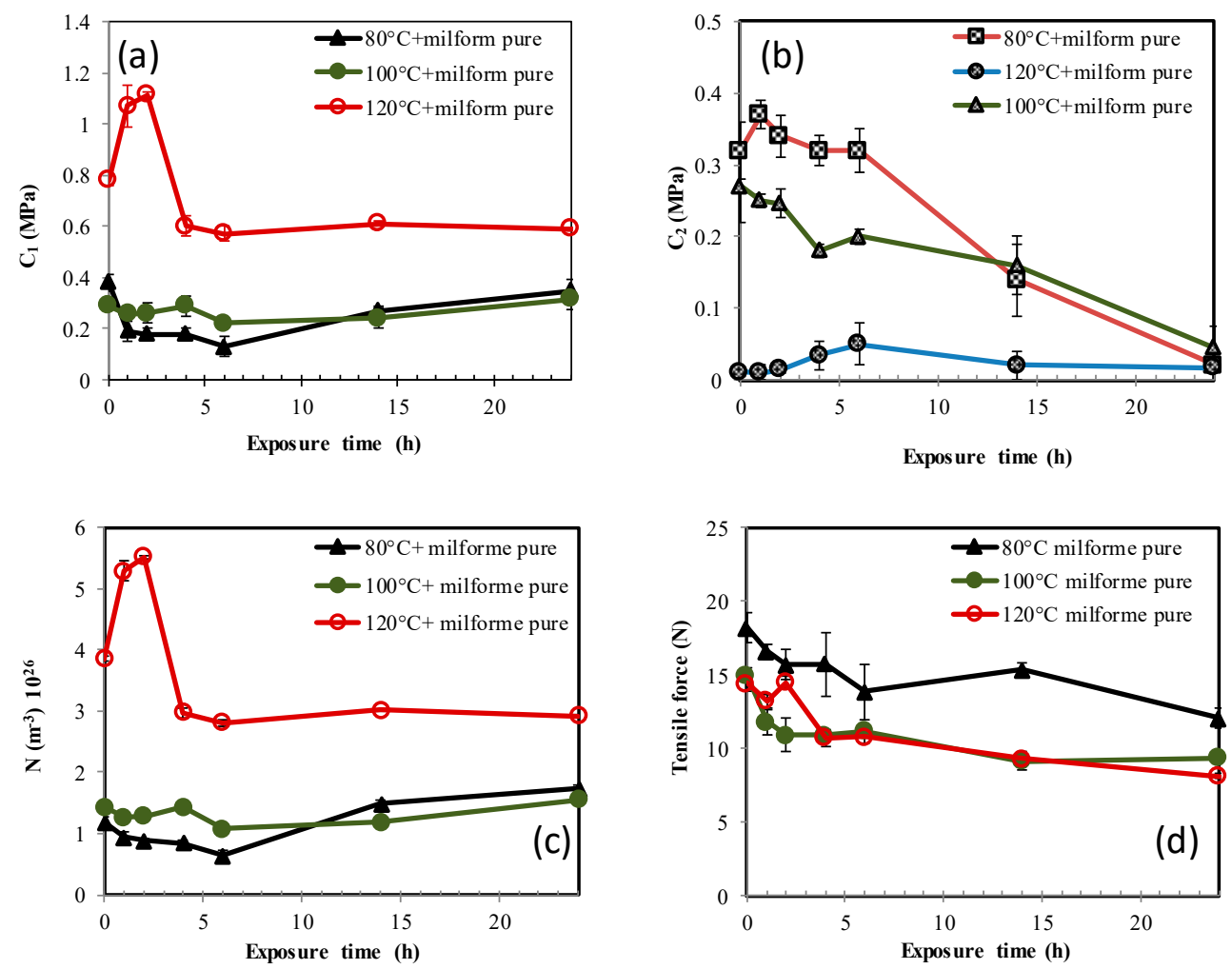

Figure 2. Effect of temperature and a MWF on the mechanical properties of BRC as function of MWF exposure time (a) constant $C_{1} ;(\mathbf{b})$ constant $C_{2} ;(\mathbf{c})$ crosslinking density $(\mathrm{N}) ;(\mathbf{d})$ tensile force.

Table 2. Young's modulus values of the BRC membrane exposed at different temperatures in the presence of metalworking fluid.

\begin{tabular}{|c|c|c|c|c|c|c|}
\hline \multirow{3}{*}{ t (h) } & \multicolumn{6}{|c|}{ Exposure Temperatures } \\
\hline & \multicolumn{2}{|c|}{$80{ }^{\circ} \mathrm{C}$} & \multicolumn{2}{|c|}{$100^{\circ} \mathrm{C}$} & \multicolumn{2}{|c|}{$120^{\circ} \mathrm{C}$} \\
\hline & $E_{\text {theo }}$ & $E_{\text {exp }}$ & $\mathrm{E}_{\text {theo }}$ & $E_{\exp }$ & $\mathrm{E}_{\text {theo }}$ & $E_{\text {exp }}$ \\
\hline 0 & $3.72(0.36)$ & $2.87(0.20)$ & $3.36(0.36)$ & $2.70(0.22)$ & $4.74(0.15)$ & $4.26(0.28)$ \\
\hline 1 & $3.36(0.36)$ & $2.64(0.16)$ & $3.03(0.12)$ & $2.51(0.09)$ & $6.76(0.54)$ & $6.28(0.17)$ \\
\hline 2 & $3.12(0.30)$ & $2.43(0.08)$ & $3.03(0.20)$ & $2.52(0.01)$ & $6.78(0.09)$ & $6.46(0.01)$ \\
\hline 4 & $3.00(0.24)$ & $2.41(0.05)$ & $2.82(0.30)$ & $2.33(0.11)$ & $3.804(0.36)$ & $3.26(0.18)$ \\
\hline 6 & $2.70(0.42)$ & $2.30(0.03)$ & $2.52(0.12)$ & $2.18(0.03)$ & $3.72(0.36)$ & $3.41(0.03)$ \\
\hline 14 & $2.46(0.24)$ & $2.31(0.05)$ & $2.40(0.48)$ & $2.01(0.05)$ & $3.66(0.18)$ & $3.15(0.04)$ \\
\hline 24 & $2.22(0.36)$ & $1.98(0.02)$ & $2.16(0.42)$ & $1.92(0.06)$ & $3.64(0.04)$ & $3.06(0.05)$ \\
\hline
\end{tabular}

Note: between parentheses: standard deviation (SD), $\mathrm{E}_{\text {theo }}$ : theoretical modulus. $\mathrm{E}_{\text {exp }}$ : experimental modulus.

\subsection{Effect of Temperature and Metalworking Fuid (MWF) on Dynamical Thermo-Mechanical Properties}

Dynamical thermo-mechanical analysis (DMTA) provides access to the elastic modulus and tangent values of materials. Figure 3a shows the example of Young's modulus of the BRC membrane before and after aging at $100^{\circ} \mathrm{C}$ during $24 \mathrm{~h}$ in MWF (Milform 64SST). The curves are recorded from the temperatures $-120^{\circ} \mathrm{C}$ to $70{ }^{\circ} \mathrm{C}$. It shows that thermal degradation of the membrane in metalworking fluid significantly reduced its Young's modulus. It is clearly seen that the Young's modulus decreased from $1.45 \times 10^{7}$ to $4 \times 10^{6} \mathrm{MPa}$ at $-120^{\circ} \mathrm{C}$ after aging at $100{ }^{\circ} \mathrm{C}$ for $24 \mathrm{~h}$ of exposure. 

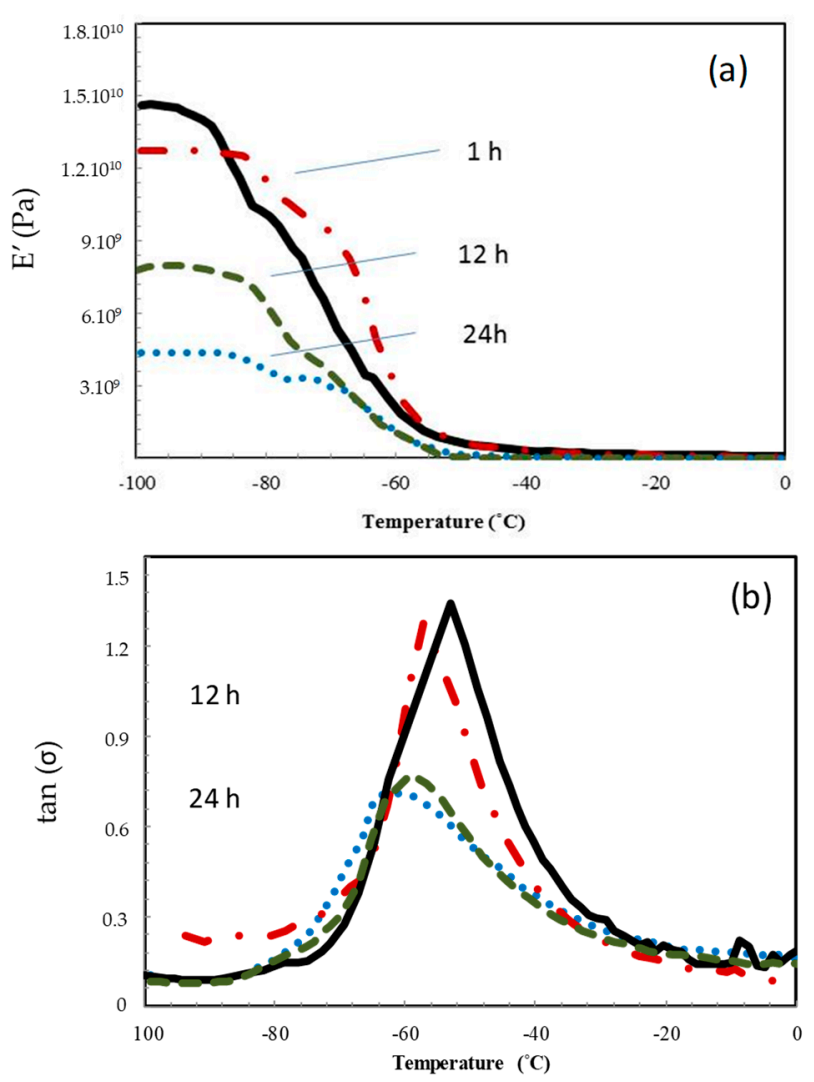

Figure 3. Evolution of storage modulus (a) and tangent delta values (b) of butyl rubber composite membrane before and after exposure in metalworking fluid (Milform 64 SST) at $100{ }^{\circ} \mathrm{C}$ for $24 \mathrm{~h}$.

For an elastomer material, the glass transition temperature $\left(\mathrm{T}_{\mathrm{g}}\right)$ is an important factor that directly involves the final properties of materials. This parameter is directly determined by DMTA curves, corresponding to the maximum peak of $\tan (\delta)$. Figure $3 \mathrm{~b}$ shows the example of the variation of $\tan (\delta)$ of aged and un-aged samples at $100{ }^{\circ} \mathrm{C}$ with different aging times. It can be seen that the curve has a transition located around at $-55^{\circ} \mathrm{C}$ due to the glass transition temperature of butyl rubber. Another peak at a higher temperature of $-8^{\circ} \mathrm{C}$ was also observed. This may be associated with the movement of the local molecular relaxation side [62,63]. These local molecular movements not only affect the viscoelastic response, but also the mechanical properties (elastic modulus, plastic deformation) and also the diffusion of solvents in the polymer matrix.

After aging at $100{ }^{\circ} \mathrm{C}$ in a metalworking fluid (Milform 64SST) for $24 \mathrm{~h}$, a significant decrease of the glass transition temperature value from $-45^{\circ} \mathrm{C}$ to $-63{ }^{\circ} \mathrm{C}$ was observed. This result is in good agreement with the literature in showing that there was a decrease of $\mathrm{T}_{\mathrm{g}}$ of $\mathrm{BRC}$ during thermal aging in silicone oil [64]. The intensity of tan peak $(\delta)$ of the aged sample was observed to be lower than that of the un-aged sample. The disappearance of the peak corresponding to the secondary transition temperature associated with the local molecular movement was observed in the aged sample. It can be attributed to the presence of MWF in the elastomer matrix and lead to a better "molecular lubrication", or it may have simply been a plasticizing effect of MWF [65]. Regarding the reduction of $\mathrm{T}_{\mathrm{g}}$, the glass transition temperature varied linearly with the molar mass and the molecular loss led to a shift of the $\mathrm{T}_{\mathrm{g}}$ to lower temperature areas [66]. The decrease of $\mathrm{T}_{\mathrm{g}}$ observed in this present study may be due to the thermal and chemical degradation of material by chains scissions that led to a reduction of the molecular mass, which can explain the deterioration of the mechanical properties of the material as shown in the previous section. 


\subsection{Effect of Temperature and MWF on Morphology, Thermal Properties and Service Lifetime of Butyl Composites}

The scanning electron microscope was used to study the changes of the BRC membrane morphology during the aging process. Figure 4a shows the SEM images of a non-aged BRC sample and a sample of butyl after aging at $100{ }^{\circ} \mathrm{C}$, not in MWF (Figure $4 \mathrm{~b}$ ) and after exposure in MWF at $100{ }^{\circ} \mathrm{C}$ at different magnifications (Figure $4 \mathrm{c}, \mathrm{d}$ ). These figures show that in the case of an unexposed sample, a large distribution of fillers in the elastomer matrix was observed (Figure 4a). However, these reinforcements were missing at the surface of the exposed sample. The appearance of holes on the surface of the aged sample was also observed, and this can be attributed to the removal of fillers that was replaced by the metalworking fluid (Figure $4 \mathrm{~b}$ ). In other studies, the same damage was observed with bromobutyl rubber when they underwent a thermal aging process [67]. During the presence of MWF at an elevated temperature, various micro cracks on the exposed sample (Figure 4c) were found due to the loss of reinforcements at the sample surface, generated by thermo-oxidation aging and the plasticization effect. This observation was clearer at a higher magnification (Figure 4d) and in good agreement with the literature [67]. The appearance of micro-cracks on rubber materials is believed to be due to the dissolving of low molecular weight molecules in the butyl composites [68]. The loss of fillers was confirmed by thermogravimetric analysis (TGA) under an argon atmosphere at the temperature range from 30 to $800{ }^{\circ} \mathrm{C}$ (Figure 5). The TGA curves show that the decomposition of BRC evolved in the same way for both aged and un-aged samples. It found that the onset decomposition temperature of an original sample was about $205^{\circ} \mathrm{C}$ with a residue of $52 \%$ at $460{ }^{\circ} \mathrm{C}$, while the onset decomposition temperature for the aged sample was about $201{ }^{\circ} \mathrm{C}$ with a residue of $42 \%$ at $460{ }^{\circ} \mathrm{C}$. In other words, the aging process led to a reduction of carbon black filler from $52 \%$ for original rubber to about $42 \%$ for the aged sample.
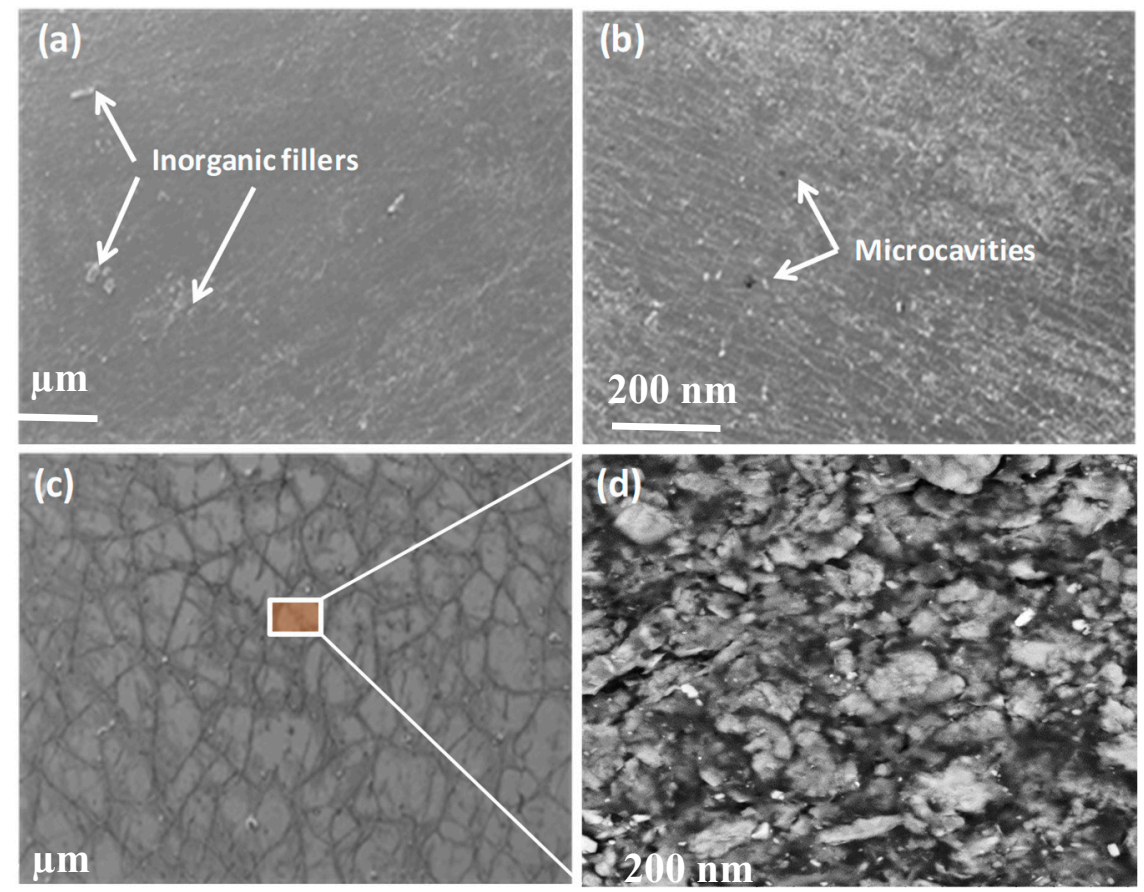

Figure 4. Scanning electron microscopy (SEM) images of butyl rubber composite membranes: (a) non-aged sample; (b) aged at $100{ }^{\circ} \mathrm{C}$, not in MWF; (c) aged at $100{ }^{\circ} \mathrm{C}$ with the presence of a metalworking fluid (Milform 64 SST) for 24 h; (d) higher magnification of Figure 4c, showing the rugosity of the sample surface. 


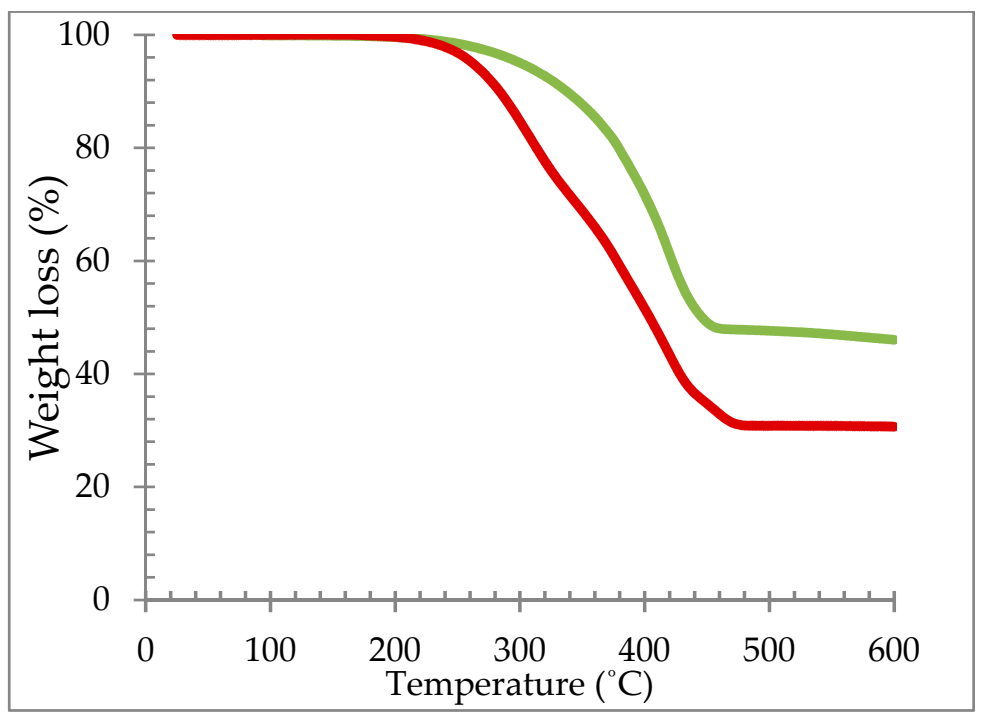

Figure 5. Thermogravimetric curves of butyl rubber composite before (green line) and after aging (red line) in Milform 64 SST at $80{ }^{\circ} \mathrm{C}$ during a week.

Changes in tensile force were observed at all studied temperatures (Figure 6). Indeed, after $24 \mathrm{~h}$ of exposure, the tensile force dropped by about $23 \%$ at $80{ }^{\circ} \mathrm{C}$, whereas it decreased by about $41 \%$ at $120^{\circ} \mathrm{C}$. The results of the tensile tests of BRC at different temperatures helped to give a prediction of the service life by applying the Arrhenius model to the time-temperature data (Equation (9)). In fact, the variation of the rate of the overall aging processes can be calculated from the aforementioned equation (Equation (9)), where $\mathrm{E}$ is activation energy, $\mathrm{R}$ is the universal constant $(8.314 \mathrm{~J} / \mathrm{mol} . \mathrm{K}), \mathrm{T}$ is absolute temperature and $\mathrm{A}$ is the pre-exponential factor. The curves describing the relationship between $\ln (\mathrm{t})$ vs. 1/T should be linear, and thus the activation energy and service life time can be calculated from this curve.

$$
\mathrm{K}=\mathrm{A} \exp (-\mathrm{E} / \mathrm{RT})
$$

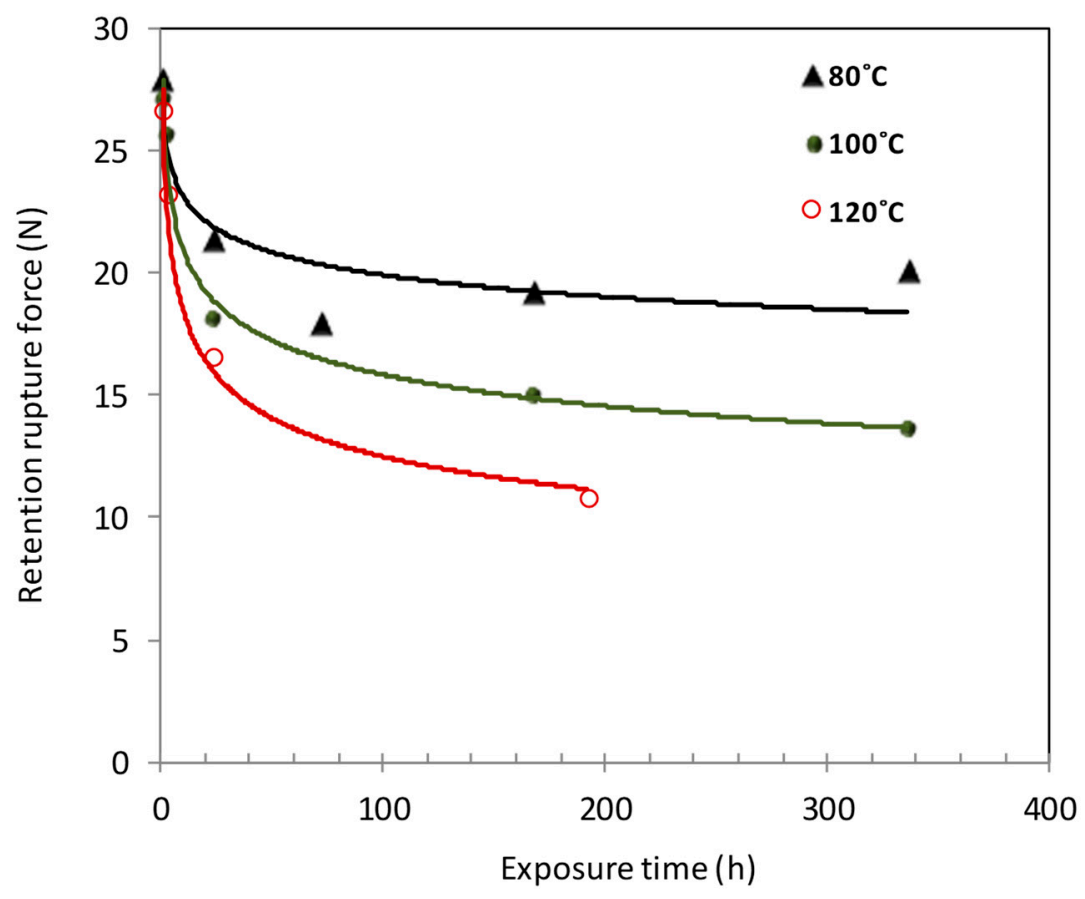

Figure 6. Variation of tensile force of BRC at different temperatures as a function of exposure time. 
The definition of the end-used service lifetime of the material is still a subject in question in the literature. However, the assumption proposed by Rachid et al. [69] in which the material is considered run out when there is a reduction of about $50 \%$ of tensile force seems to be acceptable. Here, were calculated the service lifetime for each aging temperature using an empirical regression method proposed by El Aidani et al. [16,69]. These lifetime values were exploited from the Arrhenius curve, as shown in Figure 7, by plotting the logarithm of the lifetimes as a function of the inverse of the exposed temperatures. Figure 7 shows a good agreement with the Arrhenius model, with a high linear correlation coefficient $\left(R^{2}=0.95\right)$. This indicates that the effect of the thermal treatment between 80 and $120^{\circ} \mathrm{C}$ on the tensile force of BRC can be satisfactorily described by the Arrhenius model, which can therefore be used to predict the lifetime in this range of temperatures. The results of the service lifetime of BRC can be found in Figure 6. An activation energy value of $157 \mathrm{~kJ} \cdot \mathrm{mol}^{-1}$ was obtained from the Arrhenius curve. This means that at $80^{\circ} \mathrm{C}$ the mechanical properties of $\mathrm{BRC}$ remained acceptable until 344 days, while it dropped to about 2 days at $120^{\circ} \mathrm{C}$.

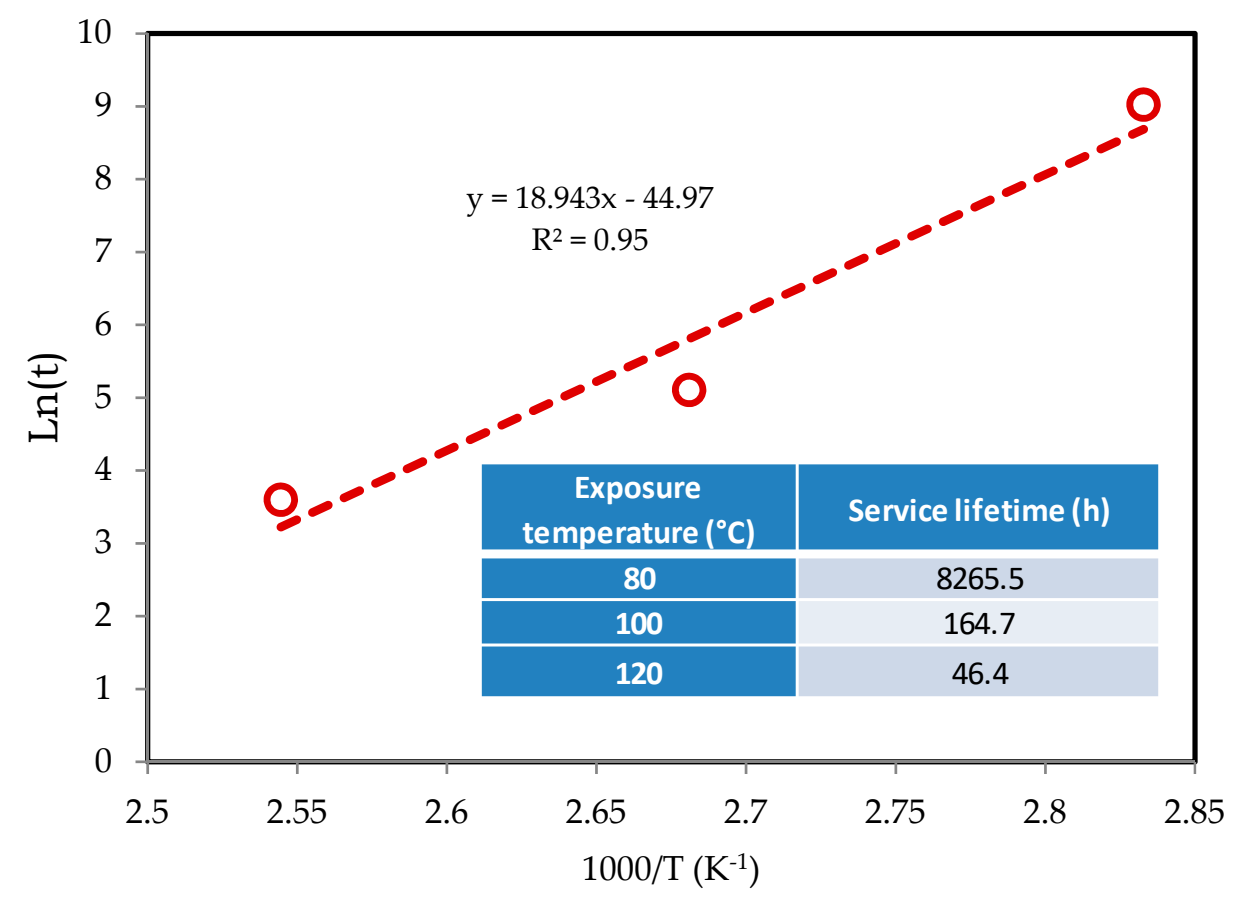

Figure 7. Extrapolation of the Arrhenius plot of the BRC membrane based on tensile force. Insert: predicted values of service lifetime, calculated from the Arrhenius plot based on tensile force at different temperatures.

\section{Conclusions}

The effect of temperature with and without MWFs on the evolution of mechanical and physico-chemical descriptors as well as the structure of BRC was investigated. The Mooney-Rivlin's theory was used to determine the changes of physical and chemical bonds and the viscoelastic behavior of BRCs when they were in contact with MWFs at high temperatures via the determination of the elastic constant $C_{1}$ and $C_{2}$ at different temperatures ranging from $80^{\circ} \mathrm{C}$ to $120^{\circ} \mathrm{C}$. The results show that temperature and MWFs led to the decrease of elastic constant $C_{2}$, suggesting a decrease of the force of cohesion of the polymer network. When BRC membranes were in contact with MWFs at high temperatures, the irreversible behavior related to the intrinsic property of elastomers was missing, and significant changes in mechanical properties of material were observed.

The temperature was found to accelerate the degradation process and the loss of mechanical properties of material was more pronounced at a high temperature. The decrease of elasticity and reduction of the glass transition temperature of BRC was also observed, implying that BRC is not 
appropriate to use in oily working conditions, particularly at a high temperature. In this case, gloves made from BRC must be changed more frequently to ensure an adequate protection level against mechanical and chemical risks. This work also provides useful information for rubber manufacturers to better understand the physicochemical degradation phenomena of their products under oily working conditions and thus improve the quality of their products.

Supplementary Materials: The following are available online at http://www.mdpi.com/2504-477X/3/2/48/s1, Figure S1: Example of Stress-Strain curves of an original BRC.

Author Contributions: P.N.-T. planned, supervised the work and wrote the manuscript. E.T. realized the experiments and participated to explain the results. T.A.N. participated in editing the manuscript.

Funding: This research was funded by the Institut de Recherche Robert-Sauvé en Santé et en Sécurité du Travail, QC, Canada (Project R-983).

Acknowledgments: Thanks also to Jaime Lara (University of Montreal) for his constant support during this project.

Conflicts of Interest: The authors declare no conflict of interest.

\section{References}

1. Youssf, O.; Hassanli, R.; Mills, J.E.; Ma, X.; Zhuge, Y. Cyclic Performance of Steel-Concrete-Steel Sandwich Beams with Rubcrete and LECA Concrete Core. J. Compos. Sci. 2019, 3, 5. [CrossRef]

2. Youssf, O.; Hassanli, R.; Mills, J.E.; Skinner, W.; Ma, X.; Zhuge, Y.; Roychand, R.; Gravina, R. Influence of Mixing Procedures, Rubber Treatment, and Fibre Additives on Rubcrete Performance. J. Compos. Sci. 2019, 3, 41. [CrossRef]

3. Aguilar-Bolados, H.; Contreras-Cid, A.; Neira-Carrillo, A.; Lopez-Manchado, M.; Yazdani-Pedram, M. Removal of Surfactant from Nanocomposites Films Based on Thermally Reduced Graphene Oxide and Natural Rubber. J. Compos. Sci. 2019, 3, 31. [CrossRef]

4. Nohilé, C.; Dolez, P.I.; Vu-Khanh, T. Mechanical and Chemical Effects of Solvent Swelling on Butyl Rubber; Wiley: Hoboken, NJ, USA, 2007. [CrossRef]

5. Ebnesajjad, S. 8-Characteristics of Adhesive Materials. In Handbook of Adhesives and Surface Preparation; Ebnesajjad, S., Ed.; William Andrew Publishing: Oxford, UK, 2011; pp. 137-183.

6. Pape, P.G. 15-Adhesion Promoters. In Handbook of Adhesives and Surface Preparation; Ebnesajjad, S., Ed.; William Andrew Publishing: Oxford, UK, 2011; pp. 369-386.

7. Rabilloud, G. 12-Adhesives for Electronics. In Handbook of Adhesives and Surface Preparation; Ebnesajjad, S., Ed.; William Andrew Publishing: Oxford, UK, 2011; pp. 259-299.

8. Rabilloud, G. 9-Heat-Resistant Adhesives. In Handbook of Adhesives and Surface Preparation; Ebnesajjad, S., Ed.; William Andrew Publishing: Oxford, UK, 2011; pp. 85-220.

9. Fabris, H.J.; Knauss, W.G. Synthetic Polymer Adhesives; Elsevier: Amsterdam, Netherlands, 1989; pp. 131-177.

10. Haworth, J.P.; Baldwin, F.P. Butyl Rubber Properties and Compounding. Ind. Eng. Chem. 1942, 34, 1301-1308. [CrossRef]

11. Ford, F.P.; Gessler, A.M. Some Properties of Butyl Rubber-Carbon Black Systems. Ind. Eng. Chem. 1952, 44, 819-824. [CrossRef]

12. Yu, B.-C.; Jung, J.-W.; Park, K.; Goodenough, J.B. A new approach for recycling waste rubber products in Li-S batteries. Energy Environ. Sci. 2017, 10, 86-90. [CrossRef]

13. $\mathrm{Xu}, \mathrm{W}$; $\mathrm{Que}$ Hee, S.S. Permeation of a Metalworking Fluid through a Latex Glove Under Field Use Conditions. Bull. Environ. Contam. Toxicol. 2009, 84, 5. [CrossRef]

14. Xu, W.; Que Hee, S.S. Swelling of four glove materials challenged by six metalworking fluids. Arch. Environ. Contam. Toxicol. 2008, 54, 1-8. [CrossRef]

15. Nguyen-Tri, P.; Prud'homme, R.E. Nanoscale Lamellar Assembly and Segregation Mechanism of Poly (3-hydroxybutyrate)/Poly (ethylene glycol) Blends. Macromolecules 2018, 51, 181-188.

16. Nguyen-Tri, P.; Malajati, Y.; Lara, J.; Vu-Khanh, T. Photochemical aging of an e-PTFE/NOMEX ${ }^{\circledR}$ membrane used in firefighter protective clothing. Polym. Degrad. Stab. 2013, 98, 1300-1310.

17. Nguyen-Tri, P.; El Aidani, R.; Leborgne, É.; Pham, T.; Vu-Khanh, T. Chemical ageingaging of a polyester nonwoven membrane used in aerosol and drainage filter. Polym. Degrad. Stab. 2014, 101, 71-80. [CrossRef] 
18. Nguyen, T.V.; Nguyen Tri, P.; Nguyen, T.D.; El Aidani, R.; Trinh, V.T.; Decker, C. Accelerated degradation of water borne acrylic nanocomposites used in outdoor protective coatings. Polym. Degrad. Stab. 2016, 128, 65-76. [CrossRef]

19. Nguyen Tri, P.; Rtimi, S.; Nguyen, T.A.; Vu, M.T. Chapter 5: Physics, Electrochemistry, Photochemistry, and Photoelectrochemistry of Hybrid Nanoparticles. In Noble Metal-Metal Oxide Hydrid Nanoparticles: Fundamentals and Applications; Elsevier: Amsterdam, The Netherlands, 2019; pp. 95-123. [CrossRef]

20. Nguyen, T.V.; Le, X.H.; Dao, P.H.; Decker, C.; Nguyen-Tri, P. Stability of acrylic polyurethane coatings under accelerated aging tests and natural outdoor exposure: The critical role of the used photo-stabilizers. Prog. Org. Coat. 2018, 124, 137-146. [CrossRef]

21. Nguyen-Tri, P.; Nguyen, T.A.; Carriere, P.; Ngo, X.C. Nanocomposite Coatings: Preparation, Characterization, Properties, and Applications. Int. J. Corros. 2018, 2018, 1-19. [CrossRef]

22. Nguyen-Tri, P.; Prud'homme, R.E. Nanoscale analysis of the photodegradation of polyester fibers by AFM-IR. J. Photochem. Photobiol. A Chem. 2019, 371, 196-204. [CrossRef]

23. Nguyen-Tri, P.; Tran, H.N.; Plamondon, C.O.; Tuduri, L.; Vo, D.-V.N.; Nanda, S.; Mishra, A.; Chao, H.-P.; Bajpai, A.K. Recent progress in the preparation, properties and applications of superhydrophobic nano-based coatings and surfaces: A review. Prog. Org. Coat. 2019, 132, 235-256. [CrossRef]

24. Nguyen-Tri, P.; Rtimi, S.; Ouellet Plamondon, C. Nanomaterials-Based Coatings: Fundamentals and Applications; Elsevier: Amsterdam, The Netherlands, 2019; Volume 1, 474p, ISBN 9780128158845.

25. Tri Phuong, N.; Gilbert, V.; Chuong, B. Preparation of Recycled Polypropylene/ Organophilic Modified Layered Silicates Nanocomposites Part I: The Recycling Process of Polypropylene and the Mechanical Properties of Recycled Polypropylene/Organoclay Nanocomposites. J. Reinf. Plast. Compos. 2008, 27, 1983-2000. [CrossRef]

26. Nguyen Tri, P.; Gilbert, V. Non-isothermal Crystallization Kinetics of Short Bamboo Fiber-reinforced Recycled Polypropylene Composites. J. Reinf. Plast. Compos. 2010, 29, 2576-2591. [CrossRef]

27. Nguyen Tri, P.; Sollogoub, C.; Guinault, A. Relationship between fiber chemical treatment and properties of recycled pp/bamboo fiber composites. J. Reinf. Plast. Compos. 2010, 29, 3244-3256. [CrossRef]

28. Boukehili, H.; Nguyen-Tri, P. Helium gas barrier and water absorption behavior of bamboo fiber reinforced recycled polypropylene. J. Reinf. Plast. Compos. 2012, 31, 1638-1651. [CrossRef]

29. Nguyen Tri, P.; Guinault, A.; Sollogoub, C. Élaboration et propriétés des composites polypropylène recyclé/fibres de bambou. Matériaux Tech. 2012, 100, 413-423. [CrossRef]

30. Triki, E.; Nguyen-Tri, P.; Boukehili, H.; Vu-Khanh, T. Investigation of tearing mechanisms of woven textile. Polym. Compos. 2012, 33, 1578-1585. [CrossRef]

31. Triki, E.; Vu-Khanh, T.; Nguyen-Tri, P.; Boukehili, H. Mechanics and mechanisms of tear resistance of woven fabrics. Theor. App. Fract. Mech. 2012, 61, 33-39. [CrossRef]

32. Tri, P.N.; Domenek, S.; Guinault, A.; Sollogoub, C. Crystallization behavior of poly(lactide)/ poly( $\beta$-hydroxybutyrate)/talc composites. J. Appl. Polym. Sci. 2013, 129, 3355-3365. [CrossRef]

33. Triki, E.; Nguyen-Tri, P.; Gauvin, C.; Azaiez, M.; Vu-Khanh, T. Combined puncture/cutting of elastomer membranes by pointed blades: Characterization of mechanisms. J. Appl. Polym. Sci. 2015, 132, 42150. [CrossRef]

34. Azizi, S.; David, E.; Fréchette, M.F.; Nguyen-Tri, P.; Ouellet-Plamondon, C.M. Electrical and thermal phenomena in low-density polyethylene/carbon black composites near the percolation threshold. J. Appl. Polym. Sci. 2019, 136, 47043. [CrossRef]

35. Azizi, S.; David, E.; Fréchette, M.F.; Nguyen-Tri, P.; Ouellet-Plamondon, C.M. Electrical and thermal conductivity of ethylene vinyl acetate composite with graphene and carbon black filler. Polym. Test. 2018, 72, 24-31. [CrossRef]

36. Nguyen-Tri, P.; Prud'homme, R.E. Crystallization and Segregation Behavior at the Submicrometer Scale of PCL/PEG Blends. Macromolecules 2018, 51, 7266-7273. [CrossRef]

37. Satyabrata, M.; Anh Nguyen, T.; Nguyen-Tri, P. Noble Metal-Metal Oxide Hybrid Nanoparticles; Fundamentals and Application; Elsevier: Amsterdam, The Netherlands, 2018; Volume 1, 675p, ISBN 978-0-12-814134-2.

38. Duc Chinh, V.; Speranza, G.; Migliaresi, C.; Van Chuc, N.; Minh Tan, V.; Phuong, N.-T. Synthesis of Gold Nanoparticles Decorated with Multiwalled Carbon Nanotubes (Au-MWCNTs) via Cysteaminium Chloride Functionalization. Sci. Rep. 2019, 9, 5667. [CrossRef] 
39. Nguyen Tri, P.; Nguyen, T.A.; Nguyen, T.H.; Carriere, P. Chapter 7: Antibacterial Behavior of Hybrid Nanoparticles. In Noble Metal-Metal Oxide Hydrid Nanoparticles: Fundamentals and Applications; Elsevier: Amsterdam, The Netherlands, 2019; pp. 141-155.

40. Nguyen Tri, P.; Ouellet-Plamondon, C.; Rtimi, S.; Assadi, A.A.; Nguyen, T.A. Chapter 3 Methods for Synthesis of Hybrid Nanoparticles. In Noble Metal-Metal Oxide Hydrid Nanoparticles: Fundamentals and Applications; Elsevier: Amsterdam, The Netherlands, 2019; pp. 51-63. [CrossRef]

41. Nguyen-Tri, P.; Nguyen, V.; Nguyen, T. Biological Activity and Nanostructuration of Fe3O4-Ag/High Density Polyethylene Nanocomposites. J. Compos. Sci. 2019, 3, 34. [CrossRef]

42. Ben Hassine, M.; Naït-Abdelaziz, M.; Zaïri, F.; Colin, X.; Tourcher, C.; Marque, G. Time to failure prediction in rubber components subjected to thermal ageing: A combined approach based upon the intrinsic defect concept and the fracture mechanics. Mech. Mater. 2014, 79, 15-24. [CrossRef]

43. Syed, I.H.; Vouagner, P.; Fleck, F.; Lacayo-Pineda, J. Nonlinearity in the Mechanical Response of Rubber as Investigated by High-Frequency DMA. Polymers 2019, 11, 581. [CrossRef] [PubMed]

44. Xiang, K.; Huang, G.; Zheng, J.; Wang, X.; Huang, J. Investigation on the thermal oxidative aging mechanism and lifetime prediction of butyl rubber. Macromol. Res. 2013, 21, 10-16. [CrossRef]

45. Haghtalab, A.; Rahimi, S. Study of viscoelastic properties of nanocomposites of SiO2-acrylonitrilebutadiene-styrene. J. Appl. Polym. Sci. 2013, 127, 4318-4327. [CrossRef]

46. Lewicki, J.P.; Liggat, J.J.; Hayward, D.; Pethrick, R.A.; Patel, M. Degradative Thermal Analysis and Dielectric Spectroscopy Studies of Aging in Polysiloxane Nanocomposites. ACS Symp. Ser. 2009, 1004, 239-254.

47. Rivlin, R.S. Large Elastic Deformations of Isotropic Materials. IV. Further Developments of the General Theory. Philos. Trans. R. Soc. A Math. Phys. Eng. Sci. 1948, 241, 379-397. [CrossRef]

48. Rivlin, R.S. Large Elastic Deformations of Isotropic Materials. I. Fundamental Concepts. Philos. Trans. R. Soc. A Math. Phys. Eng. Sci. 1948, 240, 459-490. [CrossRef]

49. Arimoto, H. $\alpha-\gamma$ Transition of nylon 6. J. Polym. Sci. Part A Gen. Pap. 1964, 2, 2283-2295. [CrossRef]

50. Slichter, W.P. Molecular motion in polyamides. J. Polym. Sci. 1959, 35, 77-92. [CrossRef]

51. Hagen, R.; Salmén, L.; Stenberg, B. Effects of the type of crosslink on viscoelastic properties of natural rubber. J. Polym. Sci. Part B Polym. Phys. 1996, 34, 1997-2006. [CrossRef]

52. Gordon, M. The Physics of Rubber Elasticity (Third Edition). L. R. G.; Treloar, Clarendon Press, Oxford. 1975 pp. xii + 370. Price: $£ 14.00$. Br. Polym. J. 1976, 8, 39. [CrossRef]

53. Sombatsompop, N. Investigation of Swelling Behavior of NR Vulcanisates. Polym.-Plast. Technol. Eng. 1998, 37, 19-39. [CrossRef]

54. Mark, J.E. Experimental Determinations of Crosslink Densities. Rubber Chem. Technol. 1982, 55, 762-768. [CrossRef]

55. Priss, L.S. Molecular origin of constants in the theory of rubber-like elasticity considering network chains steric interaction. Pure Appl. Chem. 1981, 53, 1581-1596. [CrossRef]

56. Mark, J.E. The Constants $2 \mathrm{C}_{1}$ and $2 \mathrm{C}_{2}$ in Phenomeno-Logical Elasticity Theory and Their Dependence on Experimental Variables. Rubber Chem. Technol. 1975, 48, 495-512. [CrossRef]

57. Nguyen-Tri, P.; Tuduri, L.; Triti, E.; Gauvin, C.; Vu-Khanh, T. Swelling behavior of polymeric membranes to metalworking fluids. J. Appl. Polym. Sci. 2018, 135, 45717. [CrossRef]

58. Nguyen-Tri, P.; Triki, E.; Tuduri, L.; Gauvin, C.; Vu-Khanh, T. Effet des fluides de coupe sur la résistance à la coupure et à la perforation des gants de protection; Bibliothèque et Archives nationales du Québec ed, IRSST: Montréal, QC, Canada, 2016.

59. Ha-Anh, T.; Vu-Khanh, T. Prediction of mechanical properties of polychloroprene during thermo-oxidative aging. Polym. Test. 2005, 24, 775-780. [CrossRef]

60. Gumbrell, S.M.; Mullins, L.; Rivlin, R.S. Departures of the elastic behaviour of rubbers in simple extension from the kinetic theory. Trans. Faraday Soc. 1953, 49, 1495-1505. [CrossRef]

61. Allen, G.; Kirkham, M.J.; Padget, J.; Price, C. Thermodynamics of rubber elasticity at constant volume. Trans. Faraday Soc. 1971, 67, 1278-1292. [CrossRef]

62. Dutta, N.K.; Khastgir, D.; Tripathy, D.K. The effect of carbon black concentration on the dynamic mechanical properties of bromobutyl rubber. J. Mater. Sci. 1991, 26, 177-188. [CrossRef]

63. García, M.; Garmendia, I.; García, J. Influence of natural fiber type in eco-composites. J. Appl. Polym. Sci. 2008, 107, 2994-3004. [CrossRef] 
64. Ali, S.; Ramzan, S.; Raza, R.; Ahmed, F.; Ullah, S.; Hussain, R.; Ali, S. Thermal and Thermo-Mechanical Behavior of Butyl based Rubber Exposed to Silicon Oil at Elevated Temperature. J. Chem. Soc. Pakistan 2013, 35, 1437-1444.

65. Barrere, C.; Dal Maso, F. Résines époxy réticulées par des polyamines: Structure et propriétés. Revue de l'Institut Français du Pétrole 2006, 52, 317-335. [CrossRef]

66. Fox, T.G.; Flory, P.J. Second-Order Transition Temperatures and Related Properties of Polystyrene. I. Influence of Molecular Weight. J. Appl. Phys. 1950, 21, 581-591. [CrossRef]

67. Kannan, G.K.; Gaikewad, L.V.; Nirmala, L.; Kumar, N.S. Thermal ageing studies of bromo-butyl rubber used in NBCpersonal protective equipment. J. Sci. Ind. Res. 2010, 69, 841-849.

68. Grandcoin, J.; Boukamel, A.; Lejeunes, S. A micro-mechanically based continuum damage model for fatigue life prediction of filled rubbers. Int. J. Solids Struct. 2014, 51, 1274-1286. [CrossRef]

69. El Aidani, R.; Dolez, P.I.; Vu-Khanh, T. Effect of thermal aging on the mechanical and barrier properties of an e-PTFE/Nomex ${ }^{\circledR}$ moisture membrane used in firefighters' protective suits. J. Appl. Polym. Sci. 2011, 121, 3101-3110. [CrossRef]

(C) 2019 by the authors. Licensee MDPI, Basel, Switzerland. This article is an open access article distributed under the terms and conditions of the Creative Commons Attribution (CC BY) license (http://creativecommons.org/licenses/by/4.0/). 